bp Andrzej F. Dziuba

Uniwersytet Kardynała Stefan Wyszyńskiego w Warszawie

\title{
Spowiednik wobec penitenta z problemami bioetycznymi
}

\section{CONFESSOR AND PENITENT WITH BIOETHICAL PROBLEMS}

A confessor is not required to have special knowledge about bioethical issues. In these cases the confessor needs to discern the internal dispositions of the penitent; i.e., their repentance, conversion and the readiness to change. The minister of reconciliation needs to keep in mind that this sacrament was established for men and women who are sinners, and for this reason the confessor should receive penitents and assume their good will to be reconciled with the merciful God who is willing to be born in a humble heart.

The attack on human life touches the very core of the human person. In this area there are no light or irrelevant issues and, therefore, the confessor dealing with this problem is in contact with life and death. God is always first in the sacrament of reconciliation. Let every confessor keep in mind that the confessional is not a torture chamber but the place where the penitent experiences God's mercy and where they receive an invitation to change and to do good. The penitent should always hear the truth and receive the assurance of salvific love which, in a mysterious way, is at work in every human being independently of their shortcomings and shortfalls..

Key words: confessor, penitent bioethical problems, sacrament of reconciliation, human person.

Kwestie bioetyczne są współcześnie przedmiotem niemal we wszystkich płaszczyznach życia, m.in. rodzina szkoła, życie publiczne, 
uczelnie, nauka, ustawodawstwo i etyka. Także stanowią często zasadniczą część wyznawanych przez penitentów grzechów. Łatwo przypomnieć, że w przemianach cywilizacyjnych pojawiła się aborcja i jej zalegalizowanie przez prawo stanowione. Następnie zjawisko antykoncepcji. Dzisiaj problem sztucznego zapłodnienia - in vitro. W tym kontekście szczegółowe kwestie zamrażania embrionów, diagnostyka prenatalna, środki wczesnoporonne.

Ale to nie koniec zjawisk bioetycznych, a w związku z tym i kwestii. Oto dalsze fenomeny: opieka paliatywna i nad pacjentem umierającym, eutanazja, kwestia sedacji, granice uporczywej terapii, ulepszanie ludzkiego ciała, manipulacje genetyczne na ludzkich embrionach, normy etyczne wobec chorych na AIDS i wiele innych.

Zatem bioetyka stała się częścią współczesnego życia. Bowiem kwestie ludzkiego życia, zdrowia, seksualności i prokreacji dotykają każdego bez wyjątku. To ma bezpośrednie odniesienie do osobowego życia ludzkiego, małżeństwa i rodziny. Jednocześnie współczesna medycyna daje coraz większe możliwości ingerencji w życie, ciało i prokreację. Wobec tych i innych zjawisk musi stawać sakramentalna posługa pokuty i pojednania. Oto cztery krótkie punkty.

\section{Spowiednik}

Generalnie zauważa się u księży, zwłaszcza z dużym stażem kapłańskim, otwartość i gotowość słuchania, zwłaszcza, że pewne kwestie są nowe, czasem niełatwe do ogarnięcia. Zatem czymś bezwzględnie koniecznym jest profesjonalne przygotowanie do rozwiązywania tych kwestii w konfesjonale. Czy nie jest potrzeba specjalnego kursu z tej dziedziny, poważnego, prowadzonego przez specjalistów, na odpowiednim poziomie, zwłaszcza dla alumnów?

Konieczne jest nieustanne dokształcanie dla spowiedników. Trzeba bowiem sobie szczerze powiedzieć, że wiedza jest bardzo słaba, a nawet czy nie można odczuć, że jest to jakaś niewiedza zawiniona. Niewiedza duszpasterzy w tej dziedzinie jest bardzo poważna. Jawi się potrzeba zorganizowanych form kształcenia, także o jakości akademickiej. Może nawet jakieś studia podyplomowe z zakresu problematyki bioetycznej.

Tutaj jest potrzebna wiedza bardzo kompleksowa, bo trzeba znać nawet pewne elementy medycyny. To zaś nie jest łatwe. Co więcej, potrzebna jest specyficzna formacja spowiedników, nie tylko sama wiedza. Trzeba uświadomić spowiednikom niepowtarzalność tych szczegółowych problemów bioetycznych, np. penitent po zmianie płci, po sterylizacji czy po in vitro. 
W problemach bioetycznych raczej nie należy szukać pomocy w jakichkolwiek kazuistycznych podręcznikach. Trzeba raczej szukać i znać klucz. Zatem trzeba bardziej sięgać m.in. do encyklik Jana Pawła II Veritatis splendor ${ }^{1}$, Evangelium vitae ${ }^{2}$, a także dokumentów Kongregacji Nauki Wiary Dignitas personae ${ }^{3}$ czy Donum vitae ${ }^{4}$. Chodzi o podstawowy klucza, dzięki któremu spowiednik będzie mógł podjąć próbę rozwiązania wielu szczegółowych problemów. Takie podejście świadczy także, że spowiednik się nie zamyka i nie „,starzeje intelektualnie i teologicznie".

Kompetencje merytoryczne spowiednika są tutaj sprawą szczególnie ważną, wręcz kluczową. W przeciwnym razie będzie można spotykać, wśród spowiedników dwie skrajne opcje. Jedni będą uważać się za mądrych, ale zasłaniać się decyzjami Magisterium, których sami nie rozumieją. Często, w konsekwencji, takich spowiedników penitenci nie będą słuchać. Drudzy będą starali się na fali jakiejś otwartości Kościoła przedstawiać tezy, które są obce Magisterium. To może być źródłem zgorszenia i sprzeniewierzeniem się otrzymanemu posłannictwu ${ }^{5}$.

Tymczasem, jak mówi św. Paweł, szafarz, który pozostaje wierny tajemnicom Bożym, jest w stanie rzeczywiście prowadzić ludzi (por. 1 Kor 4,1-2). To pełnienie pokornej służby u jedynego, wspólnego dla wszystkich Pana, Jezusa Chrystusa. To pytanie o prawdziwa uczciwość i wierne przywiązanie. Kiedyś pojawi się wezwanie: „zdaj sprawę z twego zarządu" (Łk 16,2). Warto w tej posłudze pamiętać o słowach Apostoła Narodów: „Postanowiłem bowiem, będąc wśród was, nie znać niczego więcej, jak tylko Jezusa Chrystusa, i to ukrzyżowanego" (1 Kor 2,2).

1 Jan Paweł II, encyklika Veritatis splendor, Città del Vaticano 1993.

2 Jan Paweł II, encyklika Evangelium vitae, Città del Vaticano 1995.

3 Kongregacja Nauki Wiary, Instrukcja,„Dignitas personae”dotyczacaniektórych problemów bioetycznych, Città del Vaticano 2008.

$4 \quad$ Kongregacja Nauki Wiary, Instrukcja o szacunku dla rodzacego się życia ludzkiego i o godności jego przekazywania „Donum vitae”, Città del Vaticano 1987.

5 „Pasterze Kościoła muszą być przede wszystkim szafarzami miłosierdzia. Na przykład, spowiednik może popaść w niebezpieczeństwo nadmiernego rygoryzmu lub zbytniej pobłażliwości. Żadna z tych postaw nie jest miłosierna, ponieważ w takim przypadku spowiednik nie bierze odpowiedzialności za osobę. Rygorysta umywa ręce, ponieważ odsyła do przykazania. Pobłażliwy umywa ręce, mówiąc, że «to nie jest grzech» lub coś podobnego. Ludziom trzeba towarzyszyć, a rany powinny być leczone" (Kościót jest domem dla wszystkich, Papież Franciszek w rozmowie z A. Spadaro. Dom św. Marty. 19.08.2013, Przewodnik Katolicki - Dodatek, s. 9). 
Spowiednik to nie „bioetyk w konfesjonale” czy „,spowiednik wobec problemów bioetycznych". To jest bardzo niebezpieczny skrót myślowy. Sakrament pokuty nie jest miejscem spotkania z problemami, a więc ze sferą rzeczową, lecz z osobą, a więc ze sferą podmiotową. Ciągle należy podkreślać, że w sakramencie pokuty dochodzi do spotkania grzesznika z Miłosiernym Ojcem, w którym role pośrednika pełni spowiednik. To jest dotykanie miłosierdzia.

To uświadamia, że nie ma specjalistycznej spowiedzi z zakresu bioetyki. Są potrzebni ci, którzy rozeznają głównie dyspozycję penitenta, a więc jego skruchę, nawrócenie i gotowość przemiany.

\section{Penitent}

Trzeba zauważyć, że wiedza wiernych w zakresie problemów bioetycznych jest bardzo słaba, często wręcz błędna. Skomplikowanie samych procedur medycznych i zagubienie w nich wymiaru etycznego nie daje ich prawdziwego obrazu. Można przywołać przykładowo kwestię szczepionek dla dzieci produkowanych z embrionów.

Może występować celowe wprowadzenia w błąd. Nieprzekazywanie całej prawdy o proponowanej procedurze medycznej i ubieranie jej w terminologię przyjazną człowiekowi. Dlatego akceptuje się in vitro określane jako terapia leczenia niepłodności. Zatem pilnie potrzebna jest formacja intelektualna we tym zakresie.

Dość szeroko rozpowszechniona jest mentalność roszczeniowa. Często wsparta argumentacją emocjonalną. Swoista stylizacja życzeń i oczekiwań na prawo, np. prawo do dziecka, do zdrowego dziecka, do dziecka o takich czy innych oczach lub płci, prawo do śmierci eutanazji. W kontekście tych zjawisk jawi się zmieniona koncepcja medycyny. Więcej, jawią się jej nowe modele.

Model klienta (consumer model). Lekarz informuje pacjenta o wszystkich dostępnych alternatywach, a pacjent decyduje. Lekarz jest technicznym wykonawcą, realizatorem zamówienia klienta. Nie bierze się tutaj pod uwagę systemu wartości i przekonań. Autonomia pacjenta jest zasadą centralną i pierwszorzędną, a pragnienie i życzenie stają się wręcz normą i prawem.

Model umowy inaczej negocjacji (contractual oraz negotiated model). Lekarz i pacjent wychodzą w dyskurs odnoszący się do wartości i oczekiwanych działań. Staje się on tylko informatorem i równocześnie interpretatorem, który przyjmuje do wiadomości i ocenia życzenia pacjenta. Obydwoje akceptują układ, aby wspólnie decydować o dalszym losie, a nawet życzeniu pacjenta. Zawiązana umowa dotyczy 
tylko ich dwóch i nie powinna interesować żadnych innych stron czy osób trzecich.

Oto w miejsce etyki odpowiedzialności wchodzi etyka umowy. Czy to jeszcze jest etyka, a może to już rezygnacja z niej. W tym kontekście trzeba mocno pytać o pełną świadomość penitenta, o stopień jego winy moralnej. Zatem nie wolno imputować ani złej woli, świadomego zaniedbania. Trzeba zatem rozeznać rzeczywisty stan penitenta, aby podjąć z nim rzeczywistość sakramentu pokuty. Potrzebny jest stan rozmowy, wywiadu. Winno to doprowadzić do postawienia diagnozy, aby następnie podjąć leczenie. Trudno bez tego pochylić się nad tym, co niesie z sobą pacjent wrócić do integralnego widzenia sakramentu pokuty i pojednania oraz spotkania międzyosobowego.

To przecież „Szafarz [pojednania] powinien zawsze pamiętać, że sakrament ten został ustanowiony dla mężczyzn i kobiet, którzy są grzesznikami. Będzie więc przyjmował penitentów przystępujących do konfesjonału, zakładając, że poza przypadkami, kiedy są oczywiste dowody przeciwne, dobrą wolę pojednania się z miłosiernym Bogiem, która rodzi się w sercu skruszonego, pokornego (Ps 50,19)"”6.

\section{Zamach na życie}

Problematyka bioetyczna jest ważna, budzi emocje, jest ciekawa, dotyka bowiem ciągle nowych problemów. Jednak zainteresowanie nią wynika z faktu, iż dotyczy fundamentów egzystencji człowieka. Już Sobór Watykański II w Konstytucji duszpasterskiej o Kościele w świecie wspótczesnym, gdy wyliczał różnego rodzaju przejawy zagrożeń przeciw godności osoby, to jakby już podał krótki zestaw najbardziej współczesnych zagadnień bioetycznych ${ }^{7}$.

$6 \quad$ Papieska Rada ds. Rodziny, Vademecum dla spowiedników o niektórych zagadnieniach moralnych dotyczacych życia matżeńskiego, Città del Vaticano $1997 \mathrm{nr}$ 3.2. Por. T. Federici, Temi biblici della penitenza, [w:] G. Pianazzi, A. M. Triacca, Valore e attualità del sacramento della penitenza, Zurich 1974, s. 17-34.

7 „Ponadto wszystko, cokolwiek jest wrogie wobec samego życia, jak na przykład wszelkiego rodzaju zabójstwa, ludobójstwo, aborcja, eutanazja, a nawet dobrowolne samobójstwo; wszystko to, co pogwałca integralność osoby ludzkiej, jak okaleczenia i tortury zadawane ciału i umysłowi, a nawet próby zniewolenia samego ducha; wszystko to co obraża godność ludzką, jak: niegodne człowieka warunki życia, bezprawne uwięzienie, deportacja, niewola, prostytucja, handel kobietami i młodzieżą, haniebne warunki pracy (...): wszystko to i inne tego rodzaju rzeczy są hańbą, a zatruwając cywilizację ludzką, bardziej plamią tych, którzy tak postępują, niż tych, którzy doznają niesprawiedliwości, i bardzo sprzeciwiają się Stwórcy" (KDK 27). 
Fundamentalnym w tej materii jest wypowiedź Jana Pawła II w encyklice Veritatis splendor:

Źródłem i uzasadnieniem obowiązku bezwarunkowego poszanowania życia ludzkiego jest godność osoby, a nie jedynie naturalna skłonność do zachowania własnego życia fizycznego. Dlatego nawet życie ludzkie, choć jest fundamentalnym dobrem człowieka, zyskuje sens moralny dopiero przez odniesienie do dobra osoby, którą zawsze należy afirmować dla niej samej: podczas gdy zabójstwo niewinnej ludzkiej istoty pozostaje zawsze niedozwolone, to oddanie własnego życia (por. J 15,13) dla miłości bliźniego lub świadectwo prawdzie może być czynem dozwolonym i chwalebnym, a nawet obowiązkiem. (...) Naturalne skłonności zyskują bowiem znaczenie moralne jedynie o tyle, o ile odnoszą się do ludzkiej osoby i do jej prawdziwego urzeczywistnienia, które może się dokonać wyłącznie w ramach ludzkiej natury8

Natomiast kolejna encyklika Jana Pawła II Evangelium vitae krótko i jeszcze dobitniej dopowie: „Ewangelia miłości Boga do człowieka, Ewangelia godności osoby i Ewangelia życia stanowią jedną i niepodzielną Ewangelię"9.

Zatem pytania o akty penitenta dotyczące życia i zdrowia dotykają istoty chrześcijaństwa. To pytania o realizację lub naruszenie potrójnego przykazania miłości siebie samego, Boga i bliźniego (por. Mt 22, 36-40). Miłość Boga - to wspólnota naszych i Bożych pragnień. Miłość ludzi - to troska o ich sprawy, a jej miarą jest miłość siebie samego ${ }^{10}$. Dlatego Konstytucja duszpasterska o Kościele w świecie współczesnym wskazując na zagrożenia godności osoby ludzkiej apeluje do naszego sumienia, przywołując słowa Pana: „Wszystko, co uczyniliście jednemu z tych braci moich najmniejszych, Mnieście uczynili” (por. Mt 25, 40) ${ }^{11}$.

8 Jan Paweł II, encyklika Veritatis splendor, nr 50. Por. R. Tremblay, Voi, luce dell mondo... La vita morale dei Cristiani: Dio fra gli uomini, Bologna 2003, s. 66-72; R. Schnackenburg, Il Vangelo di Giovanni, t. 3. Brescia 1979, s. 30-35; R. Tremblay, Radicati e fondati nel Figlio. Contributi per una morale di tipo fifliale, Roma 1997, s. 40-44.

Jan Paweł II, encyklika Evangelium vitae, nr 2.

Por. L. Di Pinto, Amore e giustizia: il contributo specifico del vangelo di Matteo, [w:] Amore - Giustizia. Analisi semantica dei due termini e delle loro correlazioni nei testi biblici veterotestamentari e neotestamentari, G. De Gennaro (red.), L’Aquila 1980, s. 429-447; J. K. Nagórny, Teologiczna interpretacja moralności Nowego Przymierza, Lublin 1989, s. 283-302; J.-F. Collange, De Jesus à Paul: L'éthique du Nouveau Testament, Geneve 1980, s. 129-133; F. Gryglewicz, Problem miłości w Nowym Testamencie, „Ruch Biblijny i Liturgiczny” 27:1974, s. 260-261; B. Häring, L'amour du Christ, notre Loi, Paris 1968, s. 33-45.

11 Por. KDK 27; A. Feuillet, Le caractere universel du jugement et la charite sans frontieres en Mt 25,31-46, „Nouvelle Revue Theologique” 102:1980, s. 179-196; 
Idąc jeszcze dalej, można wskazać, że atak na życie i zdrowie jest faktycznie zaparciem się Boga. Może być faktycznie, u konkretnej osoby jakimś znamieniem odrzucenia kochającego Stwórcy oraz Jego miłości. Jest to delikatna granica, w której rozeznaniu bardzo pomocna jest adhortacja Jana Pawła II Reconciliatio et paenitentia ${ }^{12}$. Jest ona pomocna dla katolickiego rozeznawania grzechów. Nie powinno bowiem tutaj chodzi tylko o rodzaj, ilość czy jakość, ale o widzenie całokształtu życia konkretnego penitenta, konkretnego grzesznego człowieka. To on ukazuje swoją postawę chrześcijańską w konkretnych czynach.

Bioetyka analizuje tak podstawowe wartości osoby, że wręcz trudno mówić tutaj o sprawach błahych czy nieznaczących. Dlatego spotkanie spowiednika z tymi prawdami i problemami, które niesie konkretny penitent, winno być nacechowane szczególnym wyostrzeniem, dotykają one bowiem spraw życia i śmierci. Trzeba dodać, iż tak tej ziemskiej jak i tej wiecznej. Bowiem błędy, także po stronie spowiednika, mogą przyczynić się do śmierci. Ktoś straci życie, ponieważ wartościowanie i wskazówki były błędne. $\mathrm{Z}$ drugiej strony działający podmiot może narazić swoje życie wieczne, decydując się na zamach na życie czy zdrowie własne lub bliźniego.

\section{Pierwsze miejsce dla Boga}

Posługa w konfesjonale wymaga mądrości podejścia ojcowskiego (por. Łk 15, 11-32). To pomaga w powrotach, wzrastaniu i zwyciężaniu zła dobrem (por. Rz 12,21). To jest ta sama zasada, która odnosi się także do penitenta, który stanął przeciwko życiu. Bóg wykorzystuje najmniejszy cień nadziei w człowieku, aby go do siebie przyprowadzić i zwrócić mu naruszoną godność. Wystarczy przyjąć miłość Boga i całym sercem ją odwzajemnić. Jezus ciągle ukazuje bezgraniczną miłość Boga, Jego niepojęte miłosierdzie wobec każdego człowieka ${ }^{13}$.

W tym w sakramencie pokuty, jak i w każdym innym na pierwszym miejscu winien być Bóg. W praktyce bowiem pewna utrata wrażliwości na Boga jest jednocześnie stępieniem wrażliwości na człowieka.

V. K. Agbanou, Le discours eschatologique de Matthieu 24-25: tradition et redaction, Paris 1983, s. 170-175; J. Gnilka, Il Vangelo di Matteo, t. 2, Brescia 1991, s. 533-554.

12 Por. Jan Paweł II, adhortacja apostolska Reconciliatio et paenitentia, Città del Vaticano 1984.

13 Por. E. Bosetti, Il Figlio e i figli di Dio. Etica filiale nel Nuovo Testamento, „Rivista di Teologia Morale" 36:2004, s. 227-245; S. Zamboni, Odejście i powrót do domu Ojca: grzech i nawrócenie, [w:] Synowie w Synu. Teologia moralna fundamentalna, R. Tremblay, S. Zamboni (red.), Warszawa 2009, s. 333-338. 
Trzeba bliżej znaleźć i określić to źródło, aby następnie je zneutralizować. Zdaje się, że sama koncentracja tylko na konkretnym grzechu nie daje perspektyw odbudowania więzi z Bogiem i ludźmi. Zatem potrzebne jest tutaj raczej bardziej globalne podejście. Potrzebne jest, aby spowiednik poprowadził taką drogą, która najpierw doprowadzi do Boga. Wówczas zapewne jednocześnie rozjaśnią się problemy wyborów dotyczących życia.

Warto tutaj dodać, że niekiedy - stając wobec ludzkiej uczciwości - spowiednik winien przyznać się do pewnej bezsilności. Dlatego potrzebna jest modlitwa o rozeznanie, czasem wspólna z penitentem. Psalmowe przechodzenie penitenta przez ciemną dolinę (por. Ps 23,4) nieraz odnosi się do fundamentalnych decyzji dotyczących życia. Tutaj spowiednik nie może tylko polegać na sobie. Także on winien być człowiekiem wierzącym, przecież prawie zawsze takim jest przychodzący penitent.

Jednocześnie oznacza to, że spowiednik nie może chronić się za cytatami z Magisterium Kościoła. Nauczanie Kościoła nie może być tutaj parawanem ochronnym. Tutaj trzeba odważnie drogę dylematów moralnych i trudnych wyborów przejść razem z penitentem. To często wołanie: powiedź mi dlaczego, ale ludzkim językiem, a nie jedynie odwoływaniem się do autorytetu. Pomóż mi znaleźć rozwiązanie, a nie jedynie wygłoś wyrok. Wydaje się bowiem, że wyroki, werdykty, osądy nie nawrócą człowieka. Zdaniem Franciszka większą skuteczność ma słowo wskazujące dobro niż piętnujące zło, słowo oceniające niż osądzające ${ }^{14}$.

Zatem spowiednik ile winien mieć wiedzy i gotowości poszukiwań, ile cierpliwości i odwagi, aby towarzyszyć grzesznikowi na jego drodze szukania Boga. Często są to bardzo kręte drogi życia, zwłaszcza gdy odnoszą się do niesionych osobistych problemów z zakresu bioetyki. Takich szczegółów nie ma w podręcznikach bioetyki. Tego jednak można się ciągle uczyć na spotkaniach z Bogiem, tak spowiednicy jak i penitenci. Z tego wypływa wezwanie: Być jak Bóg, nie jak ekspert od bioetyki, bo spowiednik Jego reprezentuje wobec penitenta w konfesjonale.

Dlatego tak aktualne są słowa papieża Franciszka z Evangelii gaudium:

14 „Zamiast postrzegać nas jako ekspertów od apokaliptycznych diagnoz albo posępnych sędziów z upodobaniem doszukujących się wszelkich niebezpieczeństw lub dewiacji, byłoby dobrze, żeby nas odbierano jako radosnych zwiastunów wzniosłych propozycji, kustoszy dobra i piękna, jaśniejących w życiu wiernym Ewangelii" (Franciszek, adhortacja apostolska Evangelii gaudium, Città del Vaticano 2013, nr 168). 
Kapłanom przypominam, że konfesjonał nie powinien być sala tortur, ale miejscem miłosierdzia Pana, zachęcającego nas do czynienia możliwego dobra. Mały krok pośród wielkich ludzkich ograniczeń może bardziej podobać się Bogu, niż poprawne na zewnątrz życie człowieka, spędzającego dni bez stawiania czoła poważnym trudnościom. Do wszystkich powinna dotrzeć pociecha oraz impuls zbawczej miłości, działającej tajemniczo w każdym człowieku niezależnie od jego ułomności i upadków ${ }^{15}$.

Spowiednik wobec penitentów z problemami z zakresu bioetyki winien wsłuchać się w nauczanie Piotra naszych czasów, który wskazuje, że Kościół ma być czymś w rodzaju „szpitala polowego”, w którym najpierw winniśmy leczyć rany, udzielać pomocy, a następnie zajmować się przyczyną choroby ${ }^{16}$. Jest to ciągle aktualne oczekiwanie, aby Kościół miał ludzkie oblicze. Oby wierni, a więc i penitenci nie bali się Kościoła. Przede wszystkim, aby mieli zaufanie, nawet w sytuacjach gdy się pogubili, że nie będą odrzuceni i publicznie napiętnowani.

Zatem, na koniec, jeszcze jeden cytat z papieża Franciszka:

Wszyscy mogą w jakiś sposób uczestniczyć w życiu Kościoła: wszyscy mogą należeć do wspólnoty, i nawet drzwi sakramentów nie powinno się zamykać z byle jakich powodów. Odnosi się to przede wszystkim do sytuacji, w której chodzi o ten sakrament, który jest bramą - o Chrzest. Eucharystia, chociaż sanowi pełnię życia sakramentalnego, nie jest nagrodą dla doskonałych, lecz szlachetnym lekarstwem i pokarmem dla słabych. Przekonania te maja również konsekwencje duszpasterskie, nad którymi powinniśmy się zastanowić z roztropnością i odwagą. Często zachowujemy się jak kontrolerzy łaski, a nie jak ci, którzy ją przekazują. Kościół jednak nie jest urzędem celnym, jest ojcowskim domem, gdzie jest miejsce dla każdego z jego trudnym życiem ${ }^{17}$.

Slowa kluczowe: spowiednik, penitent, problemy bioetyczne, sakrament pojednania, osoba ludzka.

$15 \quad$ Franciszek, adhortacja apostolska Evangelii gaudium, nr 44.

16 „Wyobrażam sobie Kościół jako szpital polowy po bitwie. Nie ma sensu pytać ciężko rannego, czy ma wysoki poziom cukru i cholesterolu! Trzeba leczyć jego rany. Potem możemy mówić o całej reszcie. Leczyć rany, leczyć rany... i trzeba to rozpocząć od podstaw" (Kościółjest domem dla wszystkich, Papież Franciszek w rozmowie z A. Spadaro, s. 9). 


\section{Bibliografia:}

1. Agbanou V. K., Le discours eschatologique de Matthieu 24-25: tradition et redaction, Paris 1983.

2. Bosetti E., Il Figlio e i figli di Dio. Etica filiale nel Nuovo Testamento, „Rivista di Teologia Morale" 36:2004.

3. Collange J.-F., De Jesus à Paul: L'éthique du Nouveau Testament, Geneve 1980.

4. Di Pinto L., Amore e giustizia: il contributo specifico del vangelo di Matteo, [w:] Amore - Giustizia. Analisi semantica dei due termini e delle loro correlazioni nei testi biblici veterotestamentari e neotestamentari, G. De Gennaro (red.), L'Aquila 1980.

5. Federici T., Temi biblici della penitenza, [w:] G. Pianazzi, A. M. Triacca, Valore e attualità del sacramento della penitenza, Zurich 1974.

6. Feuillet A., Le caractere universel du jugement et la charite sans frontieres en Mt 25,31-46, „Nouvelle Revue Theologique” 102(1980).

7. Franciszek, adhortacja apostolska Evangelii gaudium, Città del Vaticano 2013.

8. Gnilka J., Il Vangelo di Matteo, t. 2, Brescia 1991.

9. Gryglewicz F., Problem miłości w Nowym Testamencie, „Ruch Biblijny i Liturgiczny" 27(1974).

10. Häring B., L'amour du Christ, notre Loi, Paris 1968.

11. Jan Paweł II, adhortacja apostolska Reconciliatio et paenitentia, Città del Vaticano 1984.

12. Jan Paweł II, ecyklika Evangelium vitae, Città del Vaticano 1995.

13. Jan Paweł II, encyklika Veritatis splendor, Città del Vaticano 1993.

14. Kongregacja Nauki Wiary, Instrukcja „Dignitas personae” dotyczaca niektórych problemów bioetycznych, Città del Vaticano 2008.

15. Kongregacja Nauki Wiary, Instrukcja o szacunku dla rodzacego się życia ludzkiego i o godności jego przekazywania „Donum vitae”, Città del Vaticano 1987.

16. Kościót jest domem dla wszystkich, Papież Franciszek w rozmowie z A. Spadaro. Dom św. Marty. 19.08.2013, Przewodnik Katolicki - Dodatek).

17. Nagórny J. K., Teologiczna interpretacja moralności Nowego Przymierza, Lublin 1989.

18. Papieska Rada ds. Rodziny, Vademecum dla spowiedników o niektórych zagadnieniach moralnych dotyczacych życia matżeńskiego, Città del Vaticano 1997.

19. Schnackenburg R., Il Vangelo di Giovanni, t. 3. Brescia 1979.

20. Tremblay R., Radicati e fondati nel Figlio. Contributi per una morale di tipo fifliale, Roma 1997.

21. Tremblay R., Voi, luce dell mondo... La vita morale dei Cristiani: Dio fra gli uomini, Bologna 2003.

22. Zamboni S., Odejście i powrót do domu Ojca: grzech i nawrócenie, [w:] R. Tremblay, S. Zamboni (red.), Synowie w Synu. Teologia moralna fundamentalna, Warszawa 2009. 